Sedum of the Trans-Mexican Volcanic Belt

An Exposition of Taxonomic Methods. By Robert T. Clausen. Pp. $\mathrm{x}+380$. (Ithaca, N.Y.: Comstock Publishing Associates, Cornell University Press ; London : Constable and Co., Ltd., 1959.) 65s. net.

7 HIS very thorough investigation of 28 species of Sedum growing in the Trans-Mexican Volcanic Belt should be noted by all those interested in modern taxonomic methods entailing population studies in the field and experimental garden as woll as the examination of herbarium specimens and literature. The author's conclusions, in his own words, are based primarily on gross morphology and ecology : only limited data about chromosomes, anatomy, embryology, etc., were available. "Such data, when used to overrule conclusions based primarily on details of gross morphology and ecology, should be based on samples sufficiently large to be of statistical significance." His own approach to the problem of sampling and the study of environmental modifications should be read by everyone working on revisions of critical north temperate plants, and his comparison (Chapter 8) of his own work on Sedum with that of his predecessors, Berger and Fröderström, is revealing. Sedum was a good genus to choose for attack by modern taxonomic methods: material is easy to propagate for cultural experiments, and "dried specimens of Sedum in herbaria are not reliable for descriptive data, regardless of how valuable they may be for indicating the distribution of species".

N. Y. SANDWITH

\section{Heredity of the Blood Groups}

By Prof. Alexander S. Wiener and Irving B. Wexler. Pp. $x+150$. (New York and London: Grune and Stratton, 1958.) n.p.

DRING the past fifteen years, as the authors point out, knowledge of the blood groups has progressed with great-rapidity, and blood grouping has become a fundamental pathological science, knowledge of which is important in many fields. The heredity of the blood groups should be clearly understood, and the authors in this book set out their conception of this ; but the book is not solely a study of the inheritance of the blood groups-it contains a good deal of serological information as well, and concludes with chapters on medico-legal applications and anthropological studies.

There is an introduction and then sections on the $\mathrm{ABO}, \mathrm{MNS}, \mathrm{P}, \mathrm{Rh}$ and other blood-group systems. The main chapter in the book, however, concerns the Rh-blood group system, and of the 146 pages in the book, about 40 are devoted to this chapter. In it are described the details of the $\mathrm{Rh}-\mathrm{Hr}$ system of notation and its various applications; anyone who is not familiar with Dr. Wiener's views on this subject will find them clearly set out in this chapter. Some of the other blood-group systems are rather sketchily dealt with, for example, the Lutheran, Duffy and Kidd systems occupying only $1-2$ pages each, but in certain instances useful information is given in a condensed form; the Kell system is a good example of this. One of the less-pleasant features of tho book is the use of bold-face type for certain of the blood group symbols; it would be better if this were discontinued. In certain of the rarer blood group systems, the authors substitute a notation of their own for that which is more widely and generally accepted by other workers. This, for example, is done in the Duffy and Kidd blood group systems; it is unfortunate that they have decided to do this.

This is a book summarizing many aspects of work on blood groups and will be of greater interest to those primarily concerned with blood groups than to the general reader.

F. STRATTON

\section{A Text-Book of Metallurgy}

By Dr. A. R. Bailey. Second edition. Pp. $x+561$. (London: Macmillan and Co., Ltd.; New York: St. Martin's Press, Inc., 1960.) 30s. net.

THE first edition of this book, published in 1954 ,

was very favourably received because it provided an elementary account embracing almost tho whole field of metallurgy, from ore-dressing to the physical behaviour of metals, written in a concise and accurate manner. The general form of this book is retained in the new edition, but the author has made many additions referring to modern developments and has provided an adequate number of up-to-dato references. The coverage of the book is so large that inevitably most subjects do not receive great depth of treatment and the level is that of first-year metallurgy at a university or the equivalent stages of a technical college course. It is a good preparation for the more specialized texts which must be used at a later stage. In any technological subject, a balance must be struck between basic theory and practice, and indeed the author of the present book succeeds in blending these two aspects to form a harmonious whole. For example, the student can find in one chapter a simple treatment of dislocations, while in another he can read an admirable account of the various mechanical working processes used in industry. The book is, in the reviewcr's opinion, the best of its kind available. It represents in these days remarkably good value for money, and students intending to read metallurgy have good reason to make it one of their first acquisitions.

\section{Annual Review of Physical Chemistry}

Vol. 10. Edited by H. Eyring, in association with C. J. Christensen and H. S. Johnston. Pp. viii +537 . (Palo Alto, Calif.: Annual Reviews, Inc., 1959.) 7 dollars.

7 HE latest volume of this well-known publication includes nineteen chapters, fewer than usual but the chapters are longer. Each has a very full list of references, and a notable feature is the inclusion of much Russian literature. The authors are British, Norwegian and American. Besides familiar topics such as thermodynamic properties, electrolytes, heterogeneous equilibria and spectra, there are chapters on copolymers, proteins, nuclear and paramagnetic resonance, and high temperatures. Each chapter covers a wide field of literature; but in spite of detail and the necessarily brief treatment the book can be read with intercst and should be intelligible to physical chemists generally. The authors have taken a good deal of trouble in this direction and have been very successful. It is impossible in a brief notice to indicate the contents of the chapters, but I found those on electrolytes and high temperatures of particular interest; other readers will certainly have different choices. This series of volumes should enable physical chemists to keep up to date in fields outside their own particular intercsts. The book is very woll produced and the price is reasonable.

J. R. Partington 